\title{
Irish geneticist takes over the helm at EMBO
}

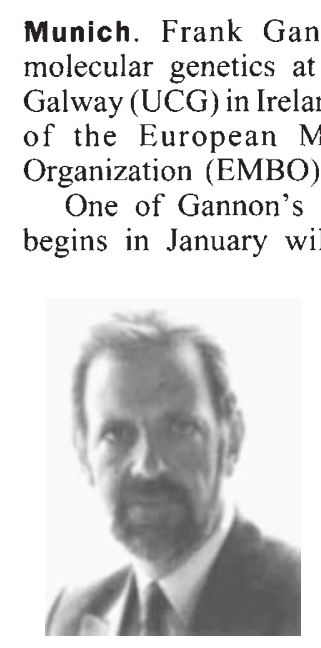

Frank Gannon Organization (EMBO). nrofessor of molecular genetics at University College of the European Molecular Biology

One of Gannon's first tasks when he be to renegotiate funding from the European Molecular Biology Conference (EMBC): their agreement must be renewed by spring 1995. The 16 member states of the EMBC this year gave EMBO DM16 million (US $\$ 10$ million) to run its programmes, courses, workshops and fellowships.

These negotiations will probably touch on the sensitive subject of EMBO's relations with the European Commission. The commission's Human Capital and Mobility fellowship is open to scientists from all disciplines and overlaps with EMBO schemes. EMBO officials complain that because the commission's grants do not always conform to local pay scales (see Nature 361, 196; 1993), researchers may find EMBO fellowships less financially attractive. Gannon's style will be to cool things down: "We will be looking for ways of working together to ensure the best interests of Europe's young molecular biologists by seeking out cooperation and partnership."

Gannon, who is 45 , was an EMBO fellow himself, in Pierre Chambon's laboratory in Strasbourg. After six years there he returned to Ireland "to establish a serious effort in molecular biology". He now leads a team of 15 researchers at UCG.

He also heads Ireland's National Diagnostics Centre. This is part of BioResearch Ireland, a government-sponsored contract research organization. Gannon began to build the centre from scratch five years ago. It now has 45 employees and is expected to have a turnover of at least IR $£ 0.5$ million (about US\$1 million) this year.

Gannon will not give up research completely: he will continue to work with both his research group and the centre for two to three years. He might then transfer his research to Heidelberg.

In the first year, Gannon will share his new job with his predecessor, John Tooze, who now works at the Imperial Cancer Research Fund in London. Tooze will also continue as editor of the EMBO Journal, whose office will stay in Heidelberg.

Alison Abbott

\section{Policy goals 'colour choice' of centres of excellence}

Tokyo. Japan's Science and Technology Agency (STA) is expected to announce late next week the selection of three "centres of excellence" from the country's many government-funded research institutes. Each will receive a welcome boost in research funds, under a new programme introduced by the STA to stimulate the work of national laboratories. But some of the criteria by which the centres are being selected seem to have little to do with academic excellence.

The idea of creating centres of excellence - or COEs, as they are called in Japanese - is the latest manifestation of the government's desire to build up national research institutions with the same status and prestige as organizations such as the Massachusetts Institute of Technology in the United States, or Germany's Max Planck institutes.

Research institutes financed by a wide variety of ministries and agencies have applied for funding from the STA scheme, which will provide $¥ 400$ million ( $\$ 3.8$ million) a year for each selected institute over the next five years. Curiously, however, some of Japan's best institutes have already been turned down, and only about six remain in the competition.

The Institute of Physical and Chemical Research (RIKEN), for example, widely acknowledged to be the best and most international of the institutes funded by the STA, was advised not to apply. Preparations to do so had already been made by the institute. But agency officials told RIKEN that in the first year they want to give the money to laboratories that are totally funded by the government, and RIKEN has some small independent sources of funds.

Another surprise has been the elimination of the National Cancer Center Research Institute in Tokyo. This operates under the Ministry of Health and Welfare, and also enjoys a strong international reputation. But the institute was not put forward by the ministry for the extra funding because it is expected to receive a substantial amount of additional money through an extension of the ten-year cancer research programme that ends next March (Nature 361, 672; 1993).

The ministry's National Institute of Health in Tokyo, which proposed to do research on AIDS, was also eliminated in the early rounds. Instead, the ministry has chosen to put forward the less well known National Cardiovascular Center Research Institute in Osaka.

The Electrotechnical Laboratory, one of the best known institutes under the Ministry of Trade and Industry (MITI), has also been eliminated from the selection process. So, too, has MITI's new National
Institute of Material and Chemical Research in Tsukuba. Rather than put either of these forward, MITI has chosen to back the National Institute of Bioscience and Human Technology in Tsukuba, which is proposing a broad programme of research on signal transduction in humans, to be carried out by molecular biologists, protein chemists and cell biologists.

STA officials refuse to discuss details of the selection procedure until the three winners are announced next week. But, according to the head of one institute, government officials decided not to include any national institutes from Tokyo in order to allow money to be pumped into local regions as part of a general government policy of decentralization.

Others suggest that each science-related ministry and agency has decided to back a single candidate - regardless of the number and quality of their research institutes - in order to maximize its chances of success. Japanese officials still seem reluctant to accept that true academic excellence will be achieved only when a system of free and open competition, regardless of government affiliation, is introduced. David Swinbanks

\section{Is pressure off Japan to contribute to SSC?}

Tokyo. Japan is asking itself whether the United States is no longer pursuing it for a contribution to Superconducting Super Collider (SSC). The reason is that US president Bill Clinton did not raise the issue during meetings with Japanese prime minister Kiichi Miyazawa either in Washington last April or in Tokyo last month.

The simple explanation is that the two leaders were too busy discussing trade and economic matters in the limited amount of time available for the meetings (one and a half hours in the case of last month's G7 meeting in Tokyo). But the difference between Clinton and George Bush, who always brought up the SCC in meetings with his Japanese counterpart, has not gone unnoticed in Japan.

The United States and Japan last held formal discussions on the matter a year ago through the joint US-Japan SSC working group. Its meetings were suspended when Clinton was elected president, and the United States has made no move to reconvene them. Resumption seems unlikely before the crucial vote in the US Senate in September, following defeat of budget appropriations for the SSC in the House of Representatives last month.

David Swinbanks 